\title{
Characterization of Modern and Fossil Mineral Dust Transported to High Altitude in the Western Alps: Saharan Sources and Transport Patterns
}

\author{
Florian Thevenon, ${ }^{1}$ Massimo Chiaradia,' ${ }^{2}$ Thierry Adatte, ${ }^{3}$ Christoph Hueglin,, ${ }^{4}$ and John \\ Poté $^{1}$
}

${ }^{1}$ Institute F.-A. Forel, University of Geneva, Versoix, Switzerland

${ }^{2}$ Department of Mineralogy, University of Geneva, Geneva, Switzerland

${ }^{3}$ Institute of Geology and Palaeontology, University of Lausanne, Lausanne, Switzerland

${ }^{4}$ Swiss Federal Laboratories for Materials Testing and Research (EMPA), Dübendorf, Switzerland

Correspondence should be addressed to Florian Thevenon, florian.thevenon@unige.ch

Received 27 September 2011; Revised 14 December 2011; Accepted 15 January 2012

Academic Editor: Ralph A. Kahn

Copyright (C) 2012 Florian Thevenon et al. This is an open access article distributed under the Creative Commons Attribution License, which permits unrestricted use, distribution, and reproduction in any medium, provided the original work is properly cited.

\begin{abstract}
Mineral dust aerosols recently collected at the high-altitude Jungfraujoch research station $\left(46^{\circ} 33^{\prime} 51^{\prime \prime} \mathrm{N}, 7^{\circ} 59^{\prime} 06^{\prime \prime} \mathrm{E} ; 3580 \mathrm{~m}\right.$ a.s.l.) were compared to mineral dust deposited at the Colle Gnifetti glacier ( $45^{\circ} 52^{\prime} 50^{\prime \prime} \mathrm{N}, 7^{\circ} 52^{\prime} 33^{\prime \prime} \mathrm{E}$; $4455 \mathrm{~m}$ a.s.l.) over the last millennium. Radiogenic isotope signatures and backward trajectories analyses indicate that major dust sources are situated in the north-central to north-western part of the Saharan desert. Less radiogenic Sr isotopic compositions of PM10 aerosols and of mineral particles deposited during periods of low dust transfer likely result from the enhancement of the background chemicallyweathered Saharan source. Saharan dust mobilization and transport were relatively reduced during the second part of the Little Ice Age (ca. 1690-1870) except within the greatest Saharan dust event deposited around 1770. After ca. 1870, sustained dust deposition suggests that increased mineral dust transport over the Alps during the last century could be due to stronger spring/summer North Atlantic southwesterlies and drier winters in North Africa. On the other hand, increasing carbonaceous particle emissions from fossil fuel combustion combined to a higher lead enrichment factor point to concomitant anthropogenic sources of particulate pollutants reaching high-altitude European glaciers during the last century.
\end{abstract}

\section{Introduction}

Polar ice core studies document enhanced atmospheric crustal dust transport during cold glacial periods, whereas dust archived in Alpine, Himalayan, and Antarctica ice cores reveals higher continental dust deposition during the 20th-century warming [1-4]. Although the long-range transported mineral dust and sea salt are the most important sources contributing to the aerosol load in Europe (altering the atmospheric circulation and the global radiative forcing [5]) there is a paucity of ice-core data about mid-latitude dust characteristics covering the preindustrial period. In order to evaluate the atmospheric dust transported over Europe during preindustrial times, we have characterized windblown mineral dust archived in an Alpine ice core over the last millennium. In fact, mineralogical and geochemical compositions of the mineral aerosols entrapped in the ice differ according to their geological sources [6]. For instance, strontium ( $\mathrm{Sr}$ ) and neodymium $(\mathrm{Nd})$ isotopic measurements of aeolian dust transported to the East Antarctica drilling sites have highlighted efficient transfer of dust from South America during cold Quaternary climatic periods [7]. Similarly, Eastern Asia desert areas were identified as being the main source of dust found in Greenland ice cores from 44 to $14 \mathrm{ka} \mathrm{BP} \mathrm{[8],} \mathrm{and} \mathrm{during} \mathrm{the} \mathrm{last} \mathrm{decade} \mathrm{[9],} \mathrm{excluding}$ Saharan dust sources. However, ice-core records also reveal complex spatial and temporal patterns of variability, whose understanding relies on the identification of the related dust 


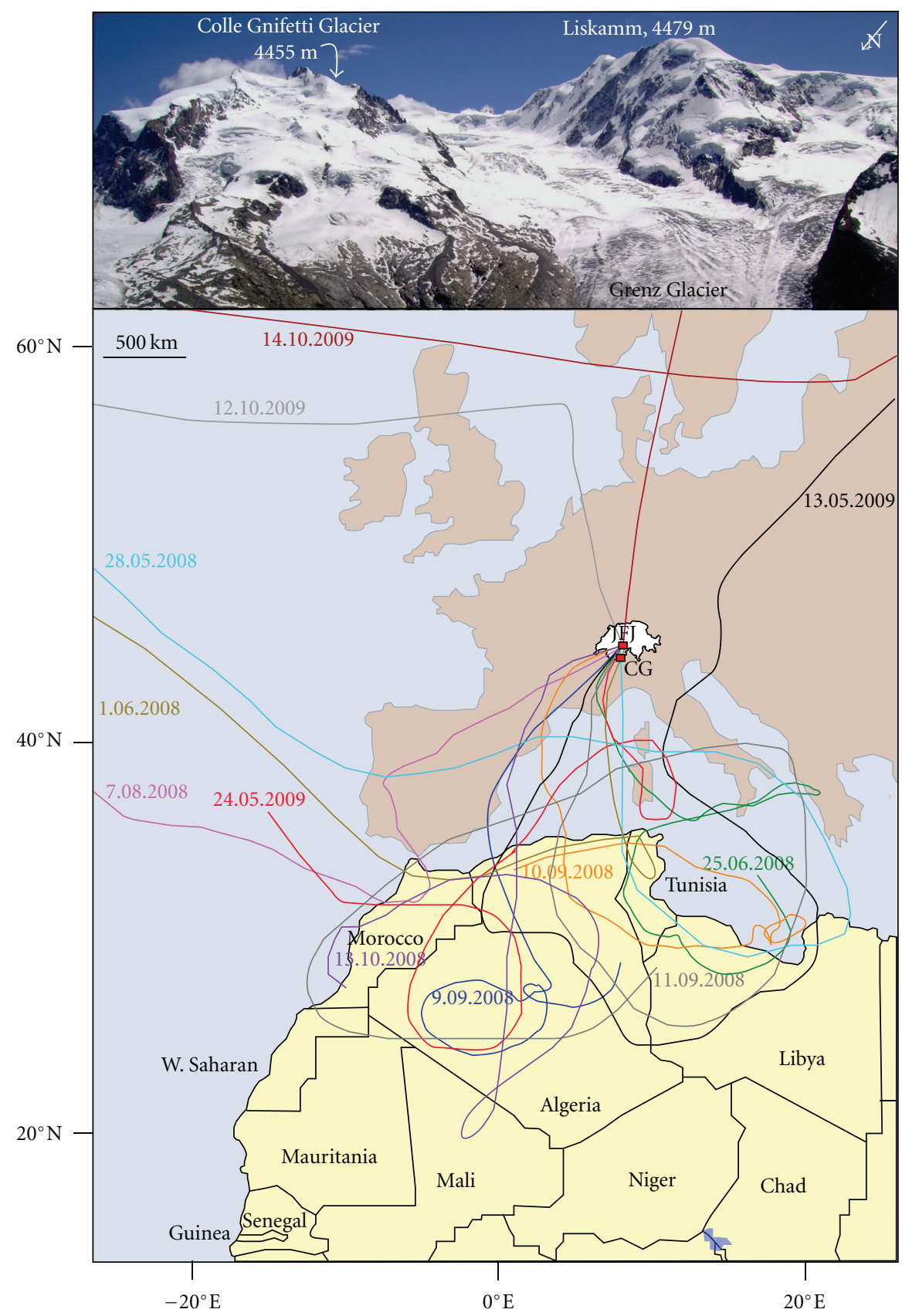

Figure 1: (Top) Panorama from the south of the Monte Rosa Massif showing the location of the ice core site (Colle Gnifetti glacier, CG) and the Grenz Glacier. (Bottom) Geographical map showing the 315-hour backward trajectories arriving at Jungfraujoch (JFJ), reconstructed using the NOAA HYSPLIT model (http://ready.arl.noaa.gov/HYSPLIT.php).

sources [10-12]. In order to identify long-range mineral dust sources and the associated circulation patterns, we have studied the insoluble dust transported to the top of the Alps during the last millennium. Mineralogical and geochemical fingerprints of the paleodust were then compared to analog aerosols, potential dust source areas, and mineral dust deposited over polar ice sheets during glacial periods.

The Sahara is the world's major source of mineral dust, which subsequently spreads across the Mediterranean and
Caribbean seas into northern South America, Central America, North America, and Europe [13, 14]. Grousset and Biscaye [6] demonstrated, by combining $\mathrm{Sr}$ and $\mathrm{Nd}$ isotopic fingerprinting and air-mass back trajectory, that the geochemical signature of Saharan dust transported to the Alps could be used for paleodust transport studies. Hence, the Colle Gnifetti glacier saddle, where the oldest glaciological record over the Alps has been recovered [15], makes a valuable candidate for reconstructing past atmospheric dust 
sources and associated transport patterns. The objectives of this study are (1) to characterize the mineralogy, geochemistry, and isotopic composition ( $\mathrm{Sr}$ and $\mathrm{Nd}$ ) of aeolian dust windborne over the Alps during the last millennium and (2) to compare the paleodust characteristics to analog aerosols collected at the Jungfraujoch high-alpine research station and to potential dust source areas and polar ice core records.

\section{Study Sites}

This study was performed with the samples collected from the following.

(i) The Colle Gnifetti glacier saddle (CG, $45^{\circ} 55^{\prime} 50^{\prime \prime} \mathrm{N}$, $7^{\circ} 52^{\prime} 33^{\prime \prime} \mathrm{E}$; $4455 \mathrm{~m}$ a.s.l.; Figure 1) which is located in the Monte Rosa Massif (the second highest mountain in the Alps), on the southern side of the Alps and on the border between Switzerland and Italy. A previous study has demonstrated that the CG archive (details of core CG03 in Bolius, 2006) allows the reconstruction of long-term changes in the dynamic of the southwesterly dust-laden winds from the Sahara, in relation to variability in large-scale atmospheric circulation patterns [4].

(ii) The high-alpine research station Jungfraujoch (JFJ, $46^{\circ} 33^{\prime} 51^{\prime \prime} \mathrm{N}, \quad 7^{\circ} 59^{\prime} 06^{\prime \prime} \mathrm{E}$; $3580 \mathrm{~m}$ a.s.l.; Figure 2), which is the highest permanently manned weather station in Europe, is located at ca. $70 \mathrm{~km}$ from the CG glacier saddle. This high Alpine site is located on the northern edge of the Swiss Alps, offering a very low background clean continental site for studying changes in the composition of the atmosphere $[16,17]$. Daily PM10 aerosol samples were collected on quartz fiber filters ( $24 \mathrm{~h}$ from midnight to midnight) within the scope of the Swiss National Air Pollution Monitoring Network (NABEL).

(iii) Fine grained sediments (till or glaciogenic clay and silt) have been collected on the Grenz Glacier $\left(45^{\circ} 57^{\prime} 54^{\prime \prime} \mathrm{N}, 7^{\circ} 48^{\prime} 18^{\prime \prime} \mathrm{E}\right.$; $2600 \mathrm{~m}$ a.s.l. $)$ in the vicinity of the confluence area of the Gorner Glacier, in order to characterize the mineralogy of the local glaciogenic potential source.

\section{Analytical Methods}

3.1. Dust Samples and Digestion Procedure. Samples from the ice core were prepared in the $-20^{\circ} \mathrm{C}$ refrigerated room at the Paul Scherrer Institute (PSI) Villigen, Switzerland. Cutting of the ice core sections and removal of possibly contaminated outer layers were performed using a precleaned stainless steel band saw. The frozen samples were then rinsed with ultrapure water (Millipore, Milli-Q, $18 \mathrm{MW}$ ) in a clean laboratory to remove possible surface contamination by dust and fibers from clothes. Subsequently, the samples were weighted and stored in precleaned polyethylene containers and melted at room temperature before being filtered. Afterward, cellulose membrane filters were mounted on smear slides using Canada balsam, in order to analyze total aerosol surface and mineral grain size by image analysis (details about the method in [4]).

The preparation of the samples for trace-element and mineral matter analyses performed in this study were done in a clean room at the Institute F. -A. Forel (University of Geneva, Switzerland) using pure acids in Teflon bombs. The cellulose membrane filters were retrieved from the smear slides (see above) and cut in two parts and placed in $1.5 \mathrm{~mL}$ of xylene in an ultrasonic bath for 10 minutes to dissolve the Canada balsam. Afterward, the original filter was removed, and $5 \mathrm{~mL}$ of Milli-Q water was added in each sample. The first half of the ice core sample was filtered on Ag filter for being analyzed by $\mathrm{X}$-ray diffraction, whereas the second part was digested in $1 \mathrm{~mL} \mathrm{HNO}_{3}$ (suprapur, $65 \%$ ), $2 \mathrm{~mL}$ of $\mathrm{HF}$ (suprapur, $40 \%$ ), and $1 \mathrm{~mL}$ of $\mathrm{HCLO}_{4}$ (suprapur, $70 \%$ ). Following evaporation at $150^{\circ} \mathrm{C}, 1 \mathrm{~mL}$ of Milli-Q water and $1 \mathrm{~mL}$ of $\mathrm{HNO}_{3}$ (suprapur, 65\%) were successively added, and the solution was left to complete evaporation between each step. The resulting solid was finally dissolved in $8 \mathrm{~mL}$ of $1 \%$ $\mathrm{HNO}_{3}$ solution for chemical analysis. About $2 \mathrm{~mL}$ was used for elemental and REE analysis by ICPMS, while the remainder was further analyzed for isotopic composition by mass spectrometry as described in Section 3.4.

Twelve ambient daily PM10 aerosols samples enriched in atmospheric dust and collected between 2008 and 2009 at the high-altitude research station JFJ were selected. The quartz fiber filters (Whatman QMA and Pallflex Tissuquartz) were placed in an ultrasonic bath for $10 \mathrm{~min}$. and prepared following the method described above. Gravimetric filter measurements (PM10) were done by the Swiss National Air Pollution Monitoring Network. When sufficient dust material was present, the mean grain-size was measured with a laser granulometer (Malvern Mastersizer) by laser diffraction, after removing the organic fraction using $\mathrm{H}_{2} \mathrm{O}_{2}$ treatment.

3.2. Mineralogical Analysis by XRD. Bulk dust and clay mineral analyses were performed on Ag filter, with an X'TRAARL (Thermo Scientific) diffractometer, using a wavelength of $\lambda=1.540562 \AA$. The peak areas of the clays were identified (20) with a WinXRXD profile-fitting program, using a Pearson-7 deconvolution function. Percentages of chlorite (C004 peak at $25.1^{\circ} 2 \theta$ Cukalpha reflection), mica (M001 peak at $8.88^{\circ}$ ), and kaolinite (K002 peak at $24.9^{\circ}$ ) were estimated using the following equations (details in [20]):

$$
\text { All Clays }=\mathrm{M} 001+\mathrm{C} 002+\mathrm{K} 001 \text {, }
$$

with

$$
\begin{aligned}
\mathrm{K} 001 & =\frac{\mathrm{K} 002}{(\mathrm{~K} 002+\mathrm{C} 004)} \times \mathrm{K} 001-\mathrm{C} 002, \\
\mathrm{C} 002 & =\frac{\mathrm{C} 004}{(\mathrm{C} 004+\mathrm{K} 002)} \times \mathrm{K} 001-\mathrm{C} 002 .
\end{aligned}
$$

3.3. Trace Element Analysis by Inductively Coupled Plasma Mass Spectrometry (ICP-MS). The concentration of trace elements ( $\mathrm{Sc}, \mathrm{Ti}, \mathrm{Cs}, \mathrm{Ba}, \mathrm{Hf}, \mathrm{Ta}, \mathrm{Pb}, \mathrm{Th}, \mathrm{U}, \mathrm{La}$ ) in the digested solution was measured using quadrupole-based inductively 
TABle 1: Sample depth (meter water equivalent, m weq.) for the Colle Gnifetti (CG) ice-core samples (upper part), sample name for the Jungfraujoch (JFJ) samples (lower part), age of sample, ${ }^{87} \mathrm{Sr} /{ }^{86} \mathrm{Sr}$ and ${ }^{143} \mathrm{Nd} /{ }^{144} \mathrm{Nd}$ isotopic compositions with $2 \sigma$ (2 standard errors of the mean), and $\mathrm{Nd}$ isotopic ratios expressed as epsilon units.

\begin{tabular}{|c|c|c|c|c|c|c|}
\hline $\begin{array}{l}\text { Sample depth } \\
\text { (m weq.) }\end{array}$ & $\begin{array}{c}\text { Apparent } \\
\text { age }^{\mathrm{a}}\end{array}$ & ${ }^{87} \mathrm{Sr} /{ }^{86} \mathrm{Sr} \mathrm{FC} C^{\mathrm{b}}$ & $2 \sigma \mathrm{Sr} \times 10^{-6}$ & $\begin{array}{c}{ }^{143} \mathrm{Nd} /{ }^{144} \mathrm{Nd} \\
\mathrm{FC}^{\mathrm{c}}\end{array}$ & $2 \sigma \mathrm{Nd} \times 10^{-6}$ & $\varepsilon_{\mathrm{Nd}}(0)^{\mathrm{d}}$ \\
\hline $10.93-10.47$ & $1974-1975$ & 0.719775 & 2 & 0.511998 & 21 & -12.5 \\
\hline $11.82-10.93$ & $1971-1974$ & 0.713703 & 14 & 0.512335 & 199 & -5.9 \\
\hline $12.25-11.82$ & 1970-1971 & 0.709416 & 12 & 0.511623 & 262 & -19.8 \\
\hline $12.71-12.25$ & $1968-1970$ & 0.717248 & 13 & 0.512081 & 68 & -10.9 \\
\hline $13.16-12.71$ & $1967-1968$ & 0.714732 & 15 & 0.511865 & 203 & -15.1 \\
\hline $17.05-15.52$ & $1952-1958$ & 0.716986 & 5 & 0.511993 & 19 & -12.6 \\
\hline $18.03-17.05$ & 1948-1952 & 0.712315 & 25 & 0.511908 & 74 & -14.2 \\
\hline $20.09-18.03$ & 1939-1948 & 0.712284 & 26 & 0.512069 & 197 & -11.1 \\
\hline $21.12-20.09$ & $1934-1939$ & 0.718733 & 14 & 0.511986 & 25 & -12.7 \\
\hline $22.74-21.12$ & 1926-1934 & 0.712936 & 51 & 0.511722 & 139 & -17.9 \\
\hline $23.92-22.74$ & 1919-1926 & 0.720629 & 3 & 0.511957 & 51 & -13.3 \\
\hline $24.52-23.92$ & 1916-1919 & 0.716637 & 20 & 0.512135 & 103 & -9.8 \\
\hline $26.18-24.52$ & 1906-1916 & 0.709494 & 42 & - & - & - \\
\hline $27.14-26.18$ & 1900-1906 & 0.723513 & 7 & 0.511929 & 18 & -13.8 \\
\hline $28.38-27.14$ & $1893-1900$ & 0.713982 & 20 & 0.512110 & 40 & -10.3 \\
\hline $29.61-28.38$ & $1884-1893$ & 0.715272 & 12 & 0.511999 & 53 & -12.5 \\
\hline $30.89-29.61$ & $1874-1884$ & 0.719117 & 2 & 0.512011 & 11 & -12.2 \\
\hline $31.50-30.89$ & $1869-1874$ & 0.714151 & 21 & 0.511907 & 108 & -14.3 \\
\hline $34.04-31.50$ & $1847-1869$ & 0.711404 & 18 & 0.512005 & 55 & -12.4 \\
\hline $36.55-34.04$ & $1821-1847$ & 0.713235 & 9 & 0.512090 & 17 & -10.7 \\
\hline $38.43-36.55$ & $1798-1821$ & 0.711326 & 10 & 0.511911 & 44 & -14.2 \\
\hline $39.10-38.43$ & $1789-1798$ & 0.716228 & 15 & 0.511956 & 25 & -13.3 \\
\hline $39.62-39.26$ & $1782-1787$ & 0.726190 & 4 & 0.511967 & 8 & -13.1 \\
\hline $41.57-39.62$ & $1751-1782$ & 0.711900 & 15 & 0.511968 & 72 & -13.1 \\
\hline $42.81-41.57$ & $1729-1751$ & 0.712842 & 6 & 0.512382 & 28 & -5.0 \\
\hline $43.43-42.81$ & $1717-1729$ & 0.712277 & 20 & - & - & - \\
\hline $44.06-43.43$ & $1704-1717$ & 0.710148 & 23 & 0.511809 & 118 & -16.2 \\
\hline $44.70-44.06$ & $1690-1704$ & 0.711321 & 16 & 0.511950 & 43 & -13.4 \\
\hline $45.33-44.70$ & $1675-1690$ & 0.712921 & 63 & 0.511975 & 53 & -12.9 \\
\hline $45.93-45.33$ & $1660-1675$ & 0.716865 & 34 & 0.512066 & 46 & -11.2 \\
\hline $46.59-45.93$ & $1642-1660$ & 0.715511 & 10 & 0.511990 & 31 & -12.6 \\
\hline $47.20-46.59$ & $1624-1642$ & 0.709537 & 15 & 0.512169 & 99 & -9.1 \\
\hline $47.81-47.20$ & $1605-1624$ & 0.712651 & 20 & 0.511995 & 66 & -12.6 \\
\hline $48.42-47.81$ & $1585-1605$ & 0.712811 & 30 & 0.511856 & 62 & -15.2 \\
\hline $49.04-48.42$ & $1563-1585$ & 0.715854 & 11 & 0.511964 & 57 & -13.2 \\
\hline $50.20-49.04$ & $1514-1563$ & 0.712714 & 37 & 0.512184 & 245 & -8.9 \\
\hline $50.62-50.20$ & $1495-1514$ & 0.714821 & 169 & 0.511771 & 43 & -16.9 \\
\hline $51.91-50.62$ & $1427-1495$ & 0.715864 & 5 & 0.511949 & 35 & -13.4 \\
\hline $54.92-53.73$ & $1187-1300$ & 0.717380 & 1 & 0.512051 & 14 & -11.5 \\
\hline A & 25.06 .2008 & 0.710311 & 2 & 0.511958 & 22 & -13.3 \\
\hline B & 07.08.2008 & 0.713474 & 24 & 0.512088 & 75 & -10.7 \\
\hline $\mathrm{C}$ & 09.09 .2008 & 0.710946 & 5 & 0.512012 & 10 & -12.2 \\
\hline $\mathrm{D}$ & 10.09 .2008 & 0.710859 & 1 & 0.512042 & 4 & -11.6 \\
\hline $\mathrm{E}$ & 12.10 .2009 & 0.710600 & 5 & 0.512063 & 19 & -11.2 \\
\hline $\mathrm{F}$ & 14.10 .2009 & 0.710728 & 5 & 0.512008 & 9 & -12.3 \\
\hline G & 13.05.2009 & 0.710740 & 2 & 0.512088 & 27 & -10.7 \\
\hline
\end{tabular}


TABle 1: Continued.

\begin{tabular}{|c|c|c|c|c|c|c|}
\hline $\begin{array}{l}\text { Sample depth } \\
\text { (m weq.) }\end{array}$ & $\begin{array}{c}\text { Apparent } \\
\text { age }^{\mathrm{a}}\end{array}$ & ${ }^{87} \mathrm{Sr} /{ }^{86} \mathrm{Sr} \mathrm{FC}$ & $2 \sigma \mathrm{Sr} \times 10^{-6}$ & $\begin{array}{c}{ }^{143} \mathrm{Nd} /{ }^{144} \mathrm{Nd} \\
\mathrm{FC}^{\mathrm{c}}\end{array}$ & $2 \sigma \mathrm{Nd} \times 10^{-6}$ & $\varepsilon_{\mathrm{Nd}}(0)^{\mathrm{d}}$ \\
\hline $\mathrm{H}$ & 24.05 .2009 & 0.710430 & 1 & 0.512064 & 33 & -11.2 \\
\hline I & 28.05 .2008 & 0.709737 & 8 & 0.512040 & 8 & -11.7 \\
\hline $\mathrm{J}$ & 01.06 .2008 & 0.710570 & 4 & 0.512057 & 21 & -11.3 \\
\hline K & 11.09 .2008 & 0.711140 & 3 & 0.512018 & 6 & -12.1 \\
\hline $\mathrm{L}$ & 13.10 .2008 & 0.712981 & 5 & 0.512036 & 20 & -11.7 \\
\hline
\end{tabular}

${ }^{a}$ The apparent age is calculated by the age model and used to plot the results. Difference between absolute and apparent ages is discussed in the text, based on ice core absolute date (e.g., Laki volcanic layer) and radiocarbon dating.

${ }^{\mathrm{b}}$ All values corrected for internal mass fractionation by normalizing to ${ }^{86} \mathrm{Sr} /{ }^{88} \mathrm{Sr}=0.1194$ and for external fractionation by normalizing the measured SRM987 values to a SRM987 nominal value of 0.710248 .

${ }^{\mathrm{c}}$ All values corrected for internal mass fractionation by normalizing to ${ }^{146} \mathrm{Nd} /{ }^{144} \mathrm{Nd}=0.7219$ and for external fractionation by normalizing the measured Jndi-1 values to a Jndi- 1 value of 0.512115 [18].

${ }^{\mathrm{d} C a l c u l a t e d}$ for a present-day CHUR value of ${ }^{143} \mathrm{Nd} /{ }^{144} \mathrm{Nd}=0.512638[19]$.

coupled plasma mass spectrometry (ICP-MS) (HP 4500, Agilent), with internal calibration by a $\mathrm{Rh} / \mathrm{Re}$ solution and multielement standard solutions at different concentrations $(0,0.02,1,5,20,100$, and $200 \mathrm{ppb})$ which were used for the calibration. Elemental equations in the 4500 ICP-MS ChemStation software were used for element interference corrections according to manufacturer's recommendations. Analytical precision of concentration measurements by ICPMS in precise mode was typically $<5 \%$ for all analyzed elements. Such precision is comparable to what was preliminarily observed for a large set of international standards certified reference materials (LKSD1-LKSD4) [21, 22]. Total variation coefficients of three replicates sample measurements were smaller than $10 \%$. The detection limit, defined as three times standard deviation of the blank resulting from the treatment of the samples (digestion in the Teflon bombs using pure acids), was checked for each element.

3.4. Isotopic Analysis by Thermal Ionization Mass Spectrometry (TRITON) Analysis. Sr and Nd separation from the solutions prepared as described above was carried out using cascade columns with Sr-spec, TRU-spec, and Ln-spec resins following a modified method after Pin et al. [26]. Sr and $\mathrm{Nd}$ isotope ratios were measured on a Thermo TRITON mass spectrometer on Faraday cups in static mode using the virtual amplifier mode to eliminate cross-calibration effects on the amplifiers. Sr was loaded on single Re filaments with a Ta oxide solution and measured at a pyrometer-controlled temperature of $1480^{\circ} \mathrm{C}$ in static mode using the virtual amplifier design to cancel out biases in gain calibration among amplifiers. ${ }^{87} \mathrm{Sr} /{ }^{86} \mathrm{Sr}$ values were internally corrected for fractionation using an ${ }^{88} \mathrm{Sr} /{ }^{86} \mathrm{Sr}$ value of 8.375209 . Raw values were further corrected for external fractionation by a value of $+0.03 \%$, determined by repeated measurements of the SRM987 standard $\left.{ }^{87} \mathrm{Sr} /{ }^{86} \mathrm{Sr}=0.710250\right)$. External reproducibility (1 s) of the SRM987 standard is $7 \mathrm{ppm}$. Nd was loaded on double Re filaments with $1 \mathrm{M} \mathrm{HNO}_{3}$ and measured in static mode with the virtual amplifier design. ${ }^{143} \mathrm{Nd} /{ }^{144} \mathrm{Nd}$ values were internally corrected for fractionation using a ${ }^{146} \mathrm{Nd} /{ }^{144} \mathrm{Nd}$ value of 0.7219 and the ${ }^{144} \mathrm{Sm}$ interference on ${ }^{144} \mathrm{Nd}$ was monitored on the mass ${ }^{147} \mathrm{Sm}$ and corrected by using a ${ }^{144} \mathrm{Sm} /{ }^{147} \mathrm{Sm}$ value of 0.206700 . External reproducibility $(1 \sigma)$ of the JNdi- 1 standard [18] is $<5 \mathrm{ppm}$. The Sr and Nd blanks introduced during column chemistry are $<10 \mathrm{pg}$.

\section{Results and Discussion}

4.1. Trace Element Composition. In the absence of the initial sample masses for the CG core dust and for the JFJ samples, the trace element concentrations $(\mathrm{Pb}, \mathrm{Ti}, \mathrm{Ba}, \mathrm{Cs}, \mathrm{U}$, and La) were normalized to conservative crustal elements ( $\mathrm{Sc}$, $\mathrm{Ta}, \mathrm{Hf}$, or Th) which primarily derive from wind-borne soil and rock-dust sources and expressed in the form of crustal enrichment factors (EFs) after normalization to the mean concentration ratios in the upper continental crust [23].

Variations in crustal element ratios are primarily influenced by total aerosol surface. Indeed, the dusty layers $\left(>30 \mathrm{~mm}^{2} / \mathrm{kg}\right.$ highlighted on Figure 2) exhibit higher trace element enrichments and larger particles $(>1 \mu \mathrm{m})$, whereas the light-colored dust layers $\left(<30 \mathrm{~mm}^{2} / \mathrm{kg}\right)$ are less enriched in heavy and/or incompatible elements and contain smaller particles. Such a distribution pattern suggests the activation of a predominant aeolian dust source (dusty layers), in conjunction with a background signal recorded during low dust deposition (light-coloured layers), rather than the contribution of a secondary source such as local dust [14, 27].

According to the geomorphology of the two high-altitude sites, surrounded by permanent glaciers, the mineral dust air concentration is known as very low and important interruptions of this background situation only occur by the advection of air masses transporting Saharan dust [13, 28, 29]. Although local dust sources such as glacial moraines or glaciogenic loess $[30,31]$ cannot be definitively ruled out as possible intermittent dust sources for the two high-altitude sites (see next sections), it is well known that Saharan dust is the dominant source of dust input to the top of the Western Alps over the last decades [1, 28, 32].

4.2. Mineralogical Composition. Mineral characterization of CG and JFJ samples reveals strong similarities between 
TABle 2: Sample depth (meter water equivalent, m weq.) for the Colle Gnifetti (CG) ice-core samples (upper part), sample name for the Jungfraujoch (JFJ) samples (middle part), and X-ray mineral composition with $\mathrm{K} / \mathrm{C}$ for kaolinite/chlorite ratio. The symbol plus (minus) shows the abundance (absence) of minerals. The composition of fine-grained sediment (till or glaciogenic clay and silt) collected on the Grenz Glacier is reported (lower part) for comparison.

\begin{tabular}{|c|c|c|c|c|c|c|c|c|}
\hline $\begin{array}{l}\text { Sample depth } \\
\text { (m weq.) }\end{array}$ & Apparent age & $\%$ Mica & $\%$ Kaolinite & \% Chlorite & $\mathrm{K} / \mathrm{C}$ & Palygorskite & Paragonite & Quartz \\
\hline $10.93-10.47$ & 1974-1975 & 41 & 38 & 12 & 3.22 & ++ & + & +++ \\
\hline $12.25-11.82$ & $1970-1971$ & 46 & 16 & 21 & 0.73 & - & + & - \\
\hline $12.71-12.25$ & $1968-1970$ & 44 & 19 & 10 & 1.86 & + & + & + \\
\hline $13.16-12.71$ & $1967-1968$ & 50 & 11 & 11 & 1.00 & + & + & - \\
\hline $17.05-15.52$ & $1952-1958$ & 41 & 25 & 17 & 1.49 & ++ & + & ++ \\
\hline $21.12-20.09$ & 1934-1939 & 45 & 18 & 12 & 1.50 & ++ & + & + \\
\hline $23.92-22.74$ & 1919-1926 & 55 & 25 & 20 & 1.21 & + & - & +++ \\
\hline $24.52-23.92$ & 1916-1919 & 57 & 23 & 20 & 1.13 & ++ & - & ++ \\
\hline $30.89-29.61$ & $1874-1884$ & 57 & 19 & 11 & 1.76 & ++ & + & ++ \\
\hline $39.26-39.10$ & $1788-1791$ & 83 & 4 & 7 & 0.58 & +++ & + & +++ \\
\hline $39.62-39.26$ & $1784-1788$ & 46 & 23 & 13 & 1.80 & +++ & + & ++ \\
\hline $49.04-48.42$ & $1563-1585$ & 62 & 16 & 22 & 0.73 & + & - & + \\
\hline $\mathrm{J}$ & 01.06 .2008 & 47 & 30 & 23 & 1.31 & ++ & - & +++ \\
\hline A & 25.06 .2008 & 34 & 22 & 45 & 0.48 & + & - & +++ \\
\hline B & 07.08 .2008 & 39 & 28 & 33 & 0.85 & + & - & +++ \\
\hline $\mathrm{C}$ & 09.09 .2008 & 52 & 23 & 25 & 0.93 & ++ & - & +++ \\
\hline $\mathrm{D}$ & 10.09 .2008 & 51 & 31 & 18 & 1.67 & ++ & + & ++ \\
\hline $\mathrm{K}$ & 11.09 .2008 & 45 & 28 & 28 & 1 & + & - & - \\
\hline $\mathrm{E}$ & 12.10.2009 & 44 & 30 & 25 & 1.19 & ++ & - & +++ \\
\hline \multicolumn{2}{|c|}{ Till of the Grenz Glacier } & 70 & - & 22 & - & - & - & +++ \\
\hline
\end{tabular}

modern and ancient dust composition (Figures 4 and 5), as well as the ubiquity of three source markers for Saharan dust that are palygorskite, kaolinite/chlorite ratio, and quartz (Table 1) [33-36]. The clay mineralogy of CG and JFJ is reported in Table 2 and compared in Figure 5, showing rather similar clay composition. Potassium feldspar and plagioclase were accessorily found in some of the ice-core and analog samples (Table 1, Figure 4). The dominant mineral group is mica, although occasional contributions of local bedrock might occur. This could be the case, for instance, of the great abundance of micas, including paragonite (Figure 4) that is present in the Southern Alps but rare in North Africa, within the end of the largest Saharan dust event located about 1790 in Figure 2. Overall, quartz and mica are common in most crystalline rock types of the Western Alps (e.g., granites, metamorphic rocks) and it is impossible to distinguish the contribution of Saharan from local dust sources based on the simple presence of these two minerals that dominate our mineral assemblages. Conversely, the presence in the JFJ and CG samples of kaolinite and palygorskite (which is typical of arid area and formed into calcretes and sebkha) identified Saharan dust, whereas these minerals were not observed in the silt and clays samples collected in the Grenz Glacier tills (Figure 4). These tills were characterized by high amount of plagioclase, serpentines, chlorite, mica, amphibole, quartz, and traces of talc and paragonite. Their location in the triangular diagram is very different than the one characterizing the dust collected on the high-altitude sites (Figure 5) due to the absence of kaolinite. Finally, the orange-brown color of the dusty layers from CG ice core ([4] and 1770 event in Figure 3) as well as the similar isotopic signature between the dust and the Saharan sources (see next section) confirms that the origin of the airborne dust reaching high-altitude Alpine glaciers from the Western Alps over the last centuries is primarily Saharan [1, 4, 28].

It is remarkable that the greatest event of the CG ice record, which encompasses a quantity of dust almost equivalent to the total remaining dust accumulated in the ice record (about 40 meters water equivalent, $\mathrm{m}$ weq.), is located between 39.62 and $39.10 \mathrm{~m}$ weq. (Figure 2, right axis), that is, between 0.81 and $0.29 \mathrm{~m}$ weq. below the Laki stratigraphic marker ( $38.81 \mathrm{~m}$ weq.) related to the Laki fissure eruption in 1783 in Iceland. According to the depth-age relationship [15], this great increase in dust deposition therefore occurs $12 \pm 2$ years before 1783 , which is $1771 \pm 2$ years. It is also important to note that the depth-age relationship is based on annual layer counting for the first 240 years, and on radiocarbon measurements of water-insoluble carbonaceous 


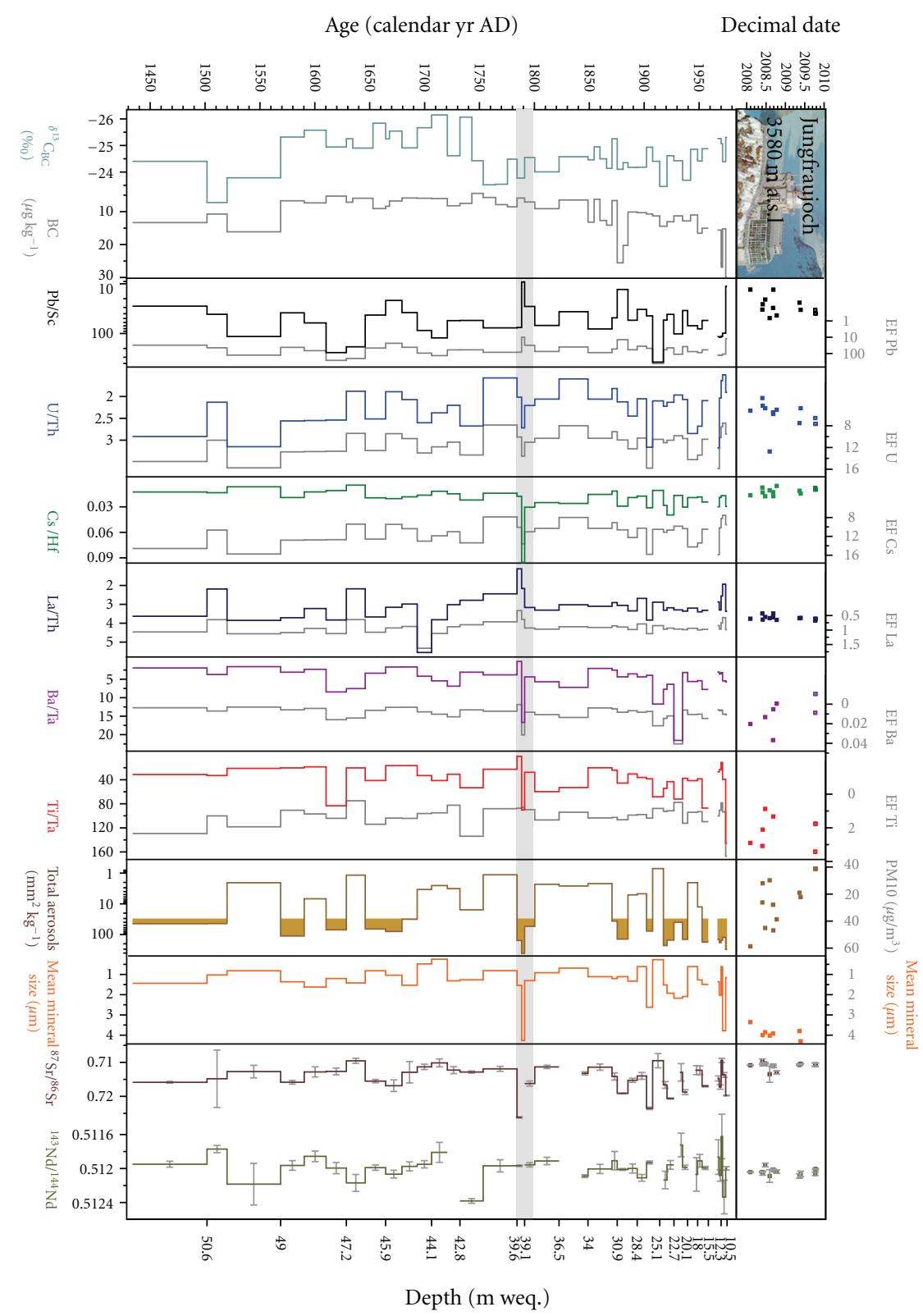

FIGURE 2: (Left Insert) Aerial view of the Jungfraujoch (JFJ) research station. The record of black carbon (BC) concentration and the associated $\delta^{13} \mathrm{C}_{\mathrm{BC}}$ composition (data from [4]), as a function of age (calendar year $\mathrm{AD}$; left axis) and depth (meter water equivalent, $\mathrm{m}$ weq.; right axis). Trace element concentrations ( $\mathrm{Pb}, \mathrm{Ti}, \mathrm{Ba}, \mathrm{Cs}, \mathrm{U}$, and $\mathrm{La}$ ) normalized to conservative crustal elements ( $\mathrm{Sc}$, Ta, $\mathrm{Hf}$, or $\mathrm{Th}$ ) and crustal enrichment factors (EFs) after normalization to the mean concentration ratios in the upper continental crust [23]. The total aerosols surface (cutoff level of $30 \mathrm{~mm}^{2} \mathrm{~kg}^{-1}$ ) and the mean diameter of the mineral fraction [4] compared to Sr and Nd isotopic ratios. The analyses of analog samples collected during the years 2008/2009 at the JFJ are reported in the upper part. ${ }^{87} \mathrm{Sr} /{ }^{86} \mathrm{Sr}$ error bars $(2$ standard errors of the mean) have been multiplied by 5 for CG samples and by 10 for JFJ samples. The horizontal grey-shaded area highlights the largest Saharan dust event deposited $\sim 10$ years before the Laki eruption in 1783 .

aerosols for the lower part of the ice core, so that the dating accuracy significantly decreases with core depth (e.g., $1443 \pm$ 55 years at 52.25-51.09 m weq.; details in [15]).

4.3. Sr and Nd Isotopic Composition. The Sr and Nd isotopic similarity between CG ice core data and possible African dust sources analyzed in the literature $[6,25]$ is remarkable
(Figure 3), demonstrating the overall Saharan origin for the paleodust reaching the high-altitude Alpine glaciers from the Western Alps and ruling out South hemisphere dust sources $[7,37]$ as well as a significant contribution of local sources to CG dust. Concerning local sources, available Sr isotope data on various rock types of the Alpine region around Colle Gnifetti [38] including gneiss, amphibolite, calc-schist of the Mount Rosa nappe and of the Piemontese ophiolite nappe as 


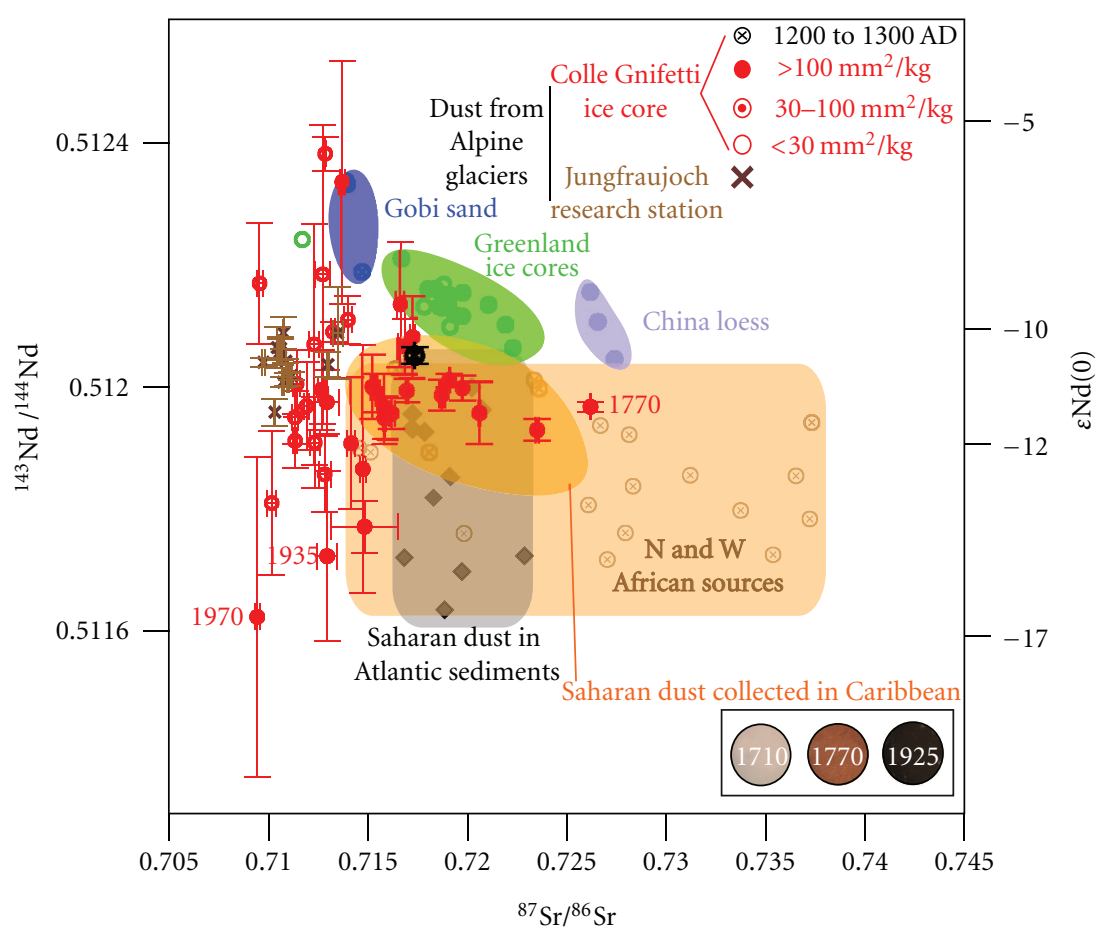

Figure 3: Sr and Nd isotopic data from Jungfraujoch samples (JFJ, crosses) and from Colle Gnifetti ice core (CG, circles) as a function of the total aerosol surface, compared to dust values from Gobi desert, China loess, Greenland ice cores (empty circles: GISP2, filled circles: GRIP), $<30 \mu \mathrm{m}$ fraction of Atlantic sediments (filled diamond), North African and central-Sahara/Sahel derived aerosols recovered over the island of La Martinique (Caribbean, empty squares), and north African sand deposits (closed circles). The digital images of three filters, respectively, depleted in insoluble minerals (ca. 1710), enriched in Saharan dust (ca.1770) and enriched in fossil fuel combustion products (ca. 1925). Data sources: Biscaye et al. [24]; Grousset et al. [25]; Svensson et al. [8]; Delmonte et al. [10]; Grousset and Biscaye [6].

well as Triassic marble have ${ }^{87} \mathrm{Sr} /{ }^{86} \mathrm{Sr}$ values in average lower than 0.712 and thus do not seem to contribute significantly to the Sr budget of the dust present in the Colle Gnifetti ice core (Figure 3). Unfortunately, at least to our knowledge, there are no systematic $\mathrm{Nd}$ isotope data on Alpine rocks of the area to further support this conclusion. However, although glaciogenic sediments are present at lower altitude (below the permanent ice cover and snow), the orographical (site surrounded by permanent glaciers and step slopes) and meteorological (cold and humid) conditions are not favorable to local sediment mobilization and transport. Events of intense vertical mixing during thunderstorms, for instance, linked to the advection of subtropical air masses (frequently loaded with Saharan dust), are accompanied by heavy rains or snow which precludes the mobilization and the transport of local dust source.

Figure 3 shows that the Saharan signature is particularly evident for the dusty CG ice-core layers $\left(>100 \mathrm{~mm}^{2}\right.$ of dust $/ \mathrm{kg}$ ) and for the sample covering one century of the Middle Age (1200 to 1300 AD). However, less radiogenic Sr ratios are observed within the light-coloured layers $\left(<30 \mathrm{~mm}^{2}\right.$ of dust $/ \mathrm{kg}$ ) or when the impact of the fossil fuel pollution becomes important, as attested by minima of ${ }^{87} \mathrm{Sr} /{ }^{86} \mathrm{Sr}$ values around 1910, 1935, and 1970, which coincide with maxima anthropogenic $\mathrm{Pb}$ deposition at CG (Figure 2) and with great lead emissions over Europe [39, 40]. Hence, $\mathrm{EF}_{\mathrm{Pb}}$ reaches ca. 375 times background level around 1920, when anthropogenic $\mathrm{Pb}$ abruptly increases because of the introduction of leaded petrol [41]. Less radiogenic Sr ratios during the industrial period could therefore reflect anthropogenic contamination (e.g., coal for power and smelting plants, traffic exhausts), rather than an alternative contribution from a deeply chemically weathered source $[14,42]$. This hypothesis may be supported by the negative correlation $\left(r^{2}=0.4\right)$ between changes in Sr isotopes ratios and $\mathrm{EF}_{\mathrm{Pb}}$ after 1910 (Figure 6).

In order to assess the environmental factor that may influence the low $\mathrm{Sr}$ isotopic ratios in the depleted aerosols samples (PM10 and $<10 \mathrm{~mm}^{2} / \mathrm{kg}$ ) before the industrialized period (before 1850), Figure 6 plots the aerosol surface, the mica, and the chlorite contents against ${ }^{87} \mathrm{Sr} /{ }^{86} \mathrm{Sr}$ values. These representations clearly illustrate changes in the $\mathrm{Sr}$ isotope composition with increasing aerosol deposition and clay characteristics. ${ }^{87} \mathrm{Sr} /{ }^{86} \mathrm{Sr}$ ratios increase with aerosol surface (or abundance) and show a fairly positive correlation with mica content and a negative one with chlorite content, probably due to the geochemical affinity of Rb with $\mathrm{K}$, which is abundant in mica but absent in chlorite (Figure 6). Physical (grain size selection) and chemical weathering processes may also explain the fact that the PM10 aerosol samples are relatively depleted in radiogenic $\mathrm{Sr}$ with respect to the CG ice core dusty samples (most of the $>100$ and $>30 \mathrm{~mm}^{2} / \mathrm{kg}$ samples) (Figure 3). Indeed $\mathrm{Sr}$ isotopic fractionation with respect to the grain size has been already evidenced in 


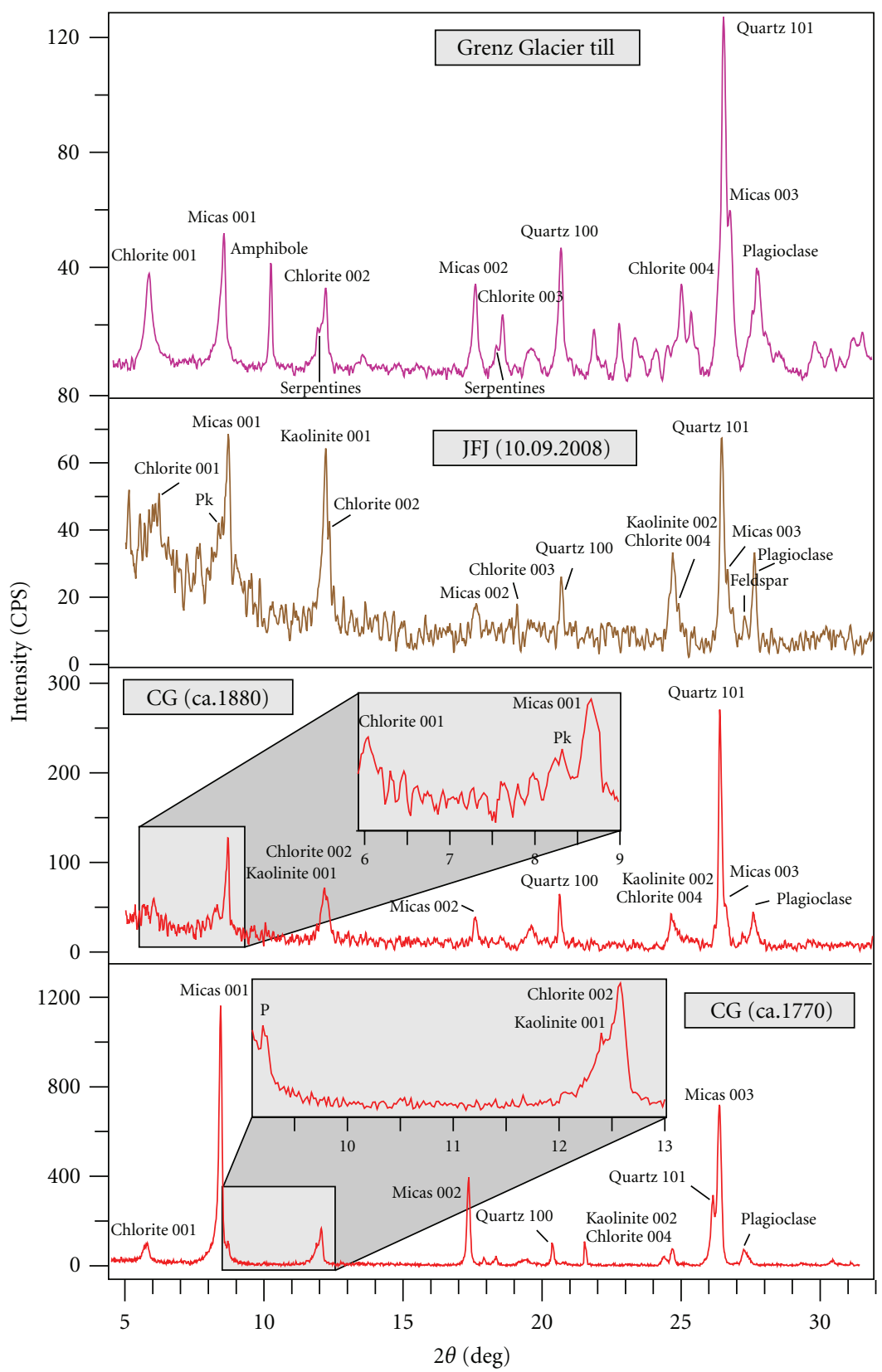

FIGURE 4: X-ray diffraction (XRD) spectra of a fine-grained sediment sample (till or glaciogenic clay and silt) collected on the Grenz Glacier, from a Jungfraujoch sample (JFJ) and from two Colle Gnifetti ice-core (CG) samples enriched in Saharan dust. The minerals and the Miller indices associated with the major peaks are indicated. P: paragonite, and Pk: palygorskite.

ice-core studies [10], and $\mathrm{Sr}$ isotopes are also significantly influenced by chemical weathering process [43]. Although the ${ }^{143} \mathrm{Nd} /{ }^{144} \mathrm{Nd}$ ratio of weathered material retains the character of the source, the radiogenic Sr fraction of a rock is preferentially removed from the source during chemical weathering [44]. Weathering processes at the source may therefore explain the low $\mathrm{Sr}$ isotopic ratio values observed in nondusty ice-core samples $\left(<30 \mathrm{~mm}^{2} / \mathrm{kg}\right)$ and JFJ samples (daily PM10 filters). In fact, the low radiogenic Sr isotope values of the local Alpine sources might be compatible with the less radiogenic Sr isotope compositions of the JFJ PM10 and the less dusty ice-core layers, but the interpretation of a background Saharan source due to weathering may be preferable given the fact that these low ${ }^{87} \mathrm{Sr} /{ }^{86} \mathrm{Sr}$ values coincide with finer-grained and lesser amounts of dust (Figures 2 and 6), which is compatible with a long-range transport process [14].

4.4. Back-Trajectories of Recent Saharan Dust Events. Airmass back-trajectories were calculated for analogs using the HYSPLIT model [45] in order to identify the source region 


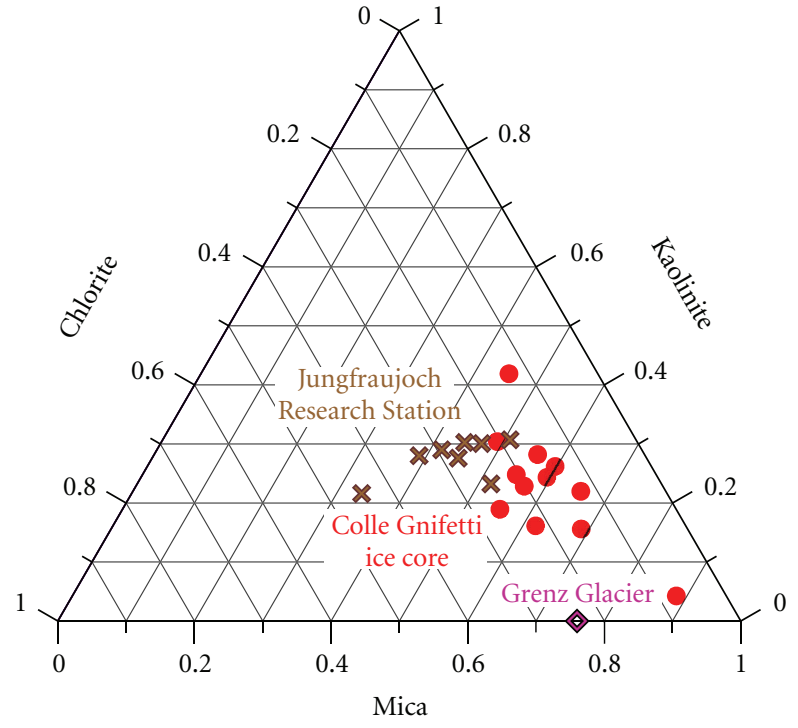

FIgURE 5: Kaolinite-mica-chlorite triangular diagram illustrating the clay mineralogy of samples from the Colle Gnifetti ice core (CG, circles), the Jungfraujoch Research Station (JFJ, crosses), and the Grenz Glacier sample (diamond).

of the paleodust reaching high-altitude Alpine areas. In order to account for transport at different altitudes and also for random deviations, the arrival points were varied both horizontally and vertically [13]. Although 10 trajectories were calculated for each selected day, only trajectories indicating paths of air masses potentially contributing to the measured Saharan dust episode are shown in Figure 1, that is, trajectories below $500 \mathrm{~m}$ a.s.l. over the African continent. The lowest vertical distance from ground defines the source country of the Sahara dust events collected at the JFJ (Table 3).

The $315 \mathrm{~h}$ back-trajectories reaching JFJ are reported in Figure 1, illustrating the control of the dust laden winds $\left(\mathrm{PM} 10 \geq 10 \mu \mathrm{g} / \mathrm{m}^{3}\right)$ by the Westerlies, except for one air-mass trajectory which originated from Northeast (13 May 2009). Generally, windborne Saharan dust was directly transported by the southwesterlies winds across the Mediterranean Sea towards the Alps, although some trajectories presented longer transport pathways (e.g., 25 June 2008). Most of the dust-laden winds originated over Algeria and to a larger extent the north-central to north-western part of the Saharan desert (i.e., Morocco, Tunisia, Libya, and Mali, Figure 1). Peculiar air masses trajectories reaching the Alps from the North occurred on the 12th and 14th October 2009, with 315-hour back-trajectories transport pathways from North America passing over Greenland and towards the Alps from northerly directions. Although the two corresponding samples are extremely depleted in insoluble material $\left(\right.$ PM10 $\left.<2 \mu \mathrm{g} / \mathrm{m}^{3}\right)$, their elemental crustal composition does not differ significantly from other JFJ samples (open squares on Figure 2). Such results therefore support our assumption of Saharan contribution not only for the strong dust events that were rapidly transported towards the Alps from southerly directions, but also for some of the longrange intercontinental dust transport reaching the Alps from northerly directions.

4.5. Long-Range Transport of Mineral Dust. Former mineral isotope analysis from dust deposition sites in the Alps, as well as air-mass back-trajectories analysis, evidences Saharan mineral dust, but also China loess, transported during several days along a pathway across the eastern North Atlantic and approaching the Alps from northerly direction $[29,32,46]$. It has been furthermore suggested that Eastern Asian dust constitutes the main source of dust deposited between ca. 26 and $23 \mathrm{ka} \mathrm{BP}$ at Summit Greenland $[8,24]$. In this context, it is meaningful to note that a dusty layer recently deposited over CG glacier carries the isotopic signature of the Gobi desert (Figure 3). Interestingly, in addition to the mixing of dust from Asian sources (Gobi sand and China loess), a possible contribution from African sources (Saharan dust) to the aeolian dust deposited over Greenland during the last glacial period cannot be definitively ruled out from the isotopic fields of dust reported on Figure 3. However, such hypothesis contradicts former interpretation based on $\mathrm{Pb}$ isotopes and clay mineralogy of the glacial dust from the Greenland ice sheet, which excluded Sahara as an important dust source for Summit Greenland [8, 24]. This statement is nevertheless supported by a two-century record of $\mathrm{Sr}$ isotopes from an ice core drilled at Mt Blanc (4300 m a.s.l., France), which concludes that aerosols reaching the Alpine glacier represent the same mixture of sources that affect the Glacial ice at Summit Greenland [32].

4.6. Paleoatmospheric Transport Patterns. The comparison of the mineral dust records from three Northern Hemisphere ice cores (Alaska, Himalayas, and Greenland) with instrumental sea-level pressure series of spring over the last century reveals consistent relationship between atmospheric circulation patterns and the long-range transport of mineral dust [47]. On a longer time scale, the high mineral dust deposition at CG, as evidenced during the first part of the Little Ice Age (LIA) (i.e., before ca. 1690), within the greatest event of the millennium (ca. 1770), and after ca. 1870, may suggest stronger spring/summer pressure gradient over the North Atlantic and winter drought conditions over North Africa [48]. By contrast, low dust deposition during the latter part of LIA (from ca. 1690 to 1870) may reflect weakened pressure gradient across the North Atlantic region and increased rainfall in northern Africa [49]. Weaker summer southwesterlies trade winds inferred from CG dust record during the latter part of the LIA could be associated with the synchronous decline of the meridional overturning circulation (MOC) and increased negative states of the North Atlantic Oscillation (NAO) [50, 51].

4.7. Anthropogenic Atmospheric Pollution. Post-1850 increase in carbonaceous residues of combustion, or black carbon (BC), and in trace elements content, highlighted the anthropogenic atmospheric pollutant emissions since the European 


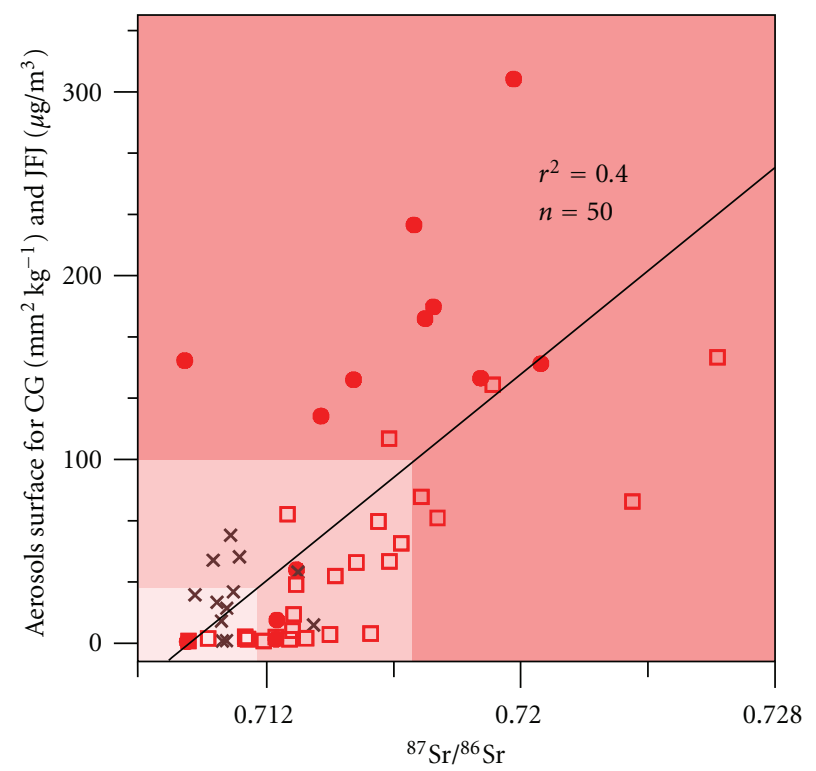

(a)

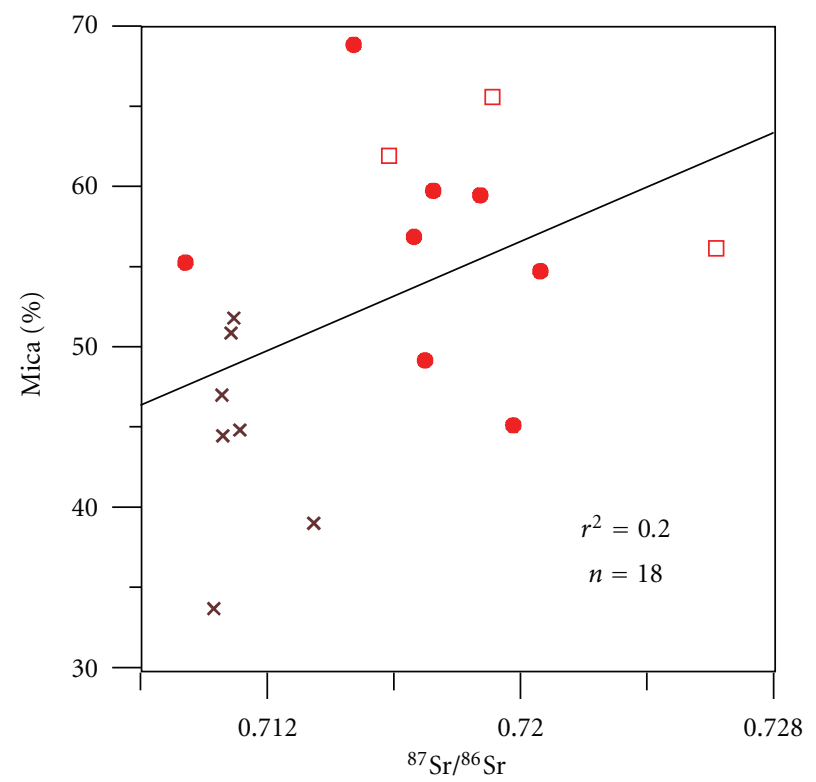

(c)

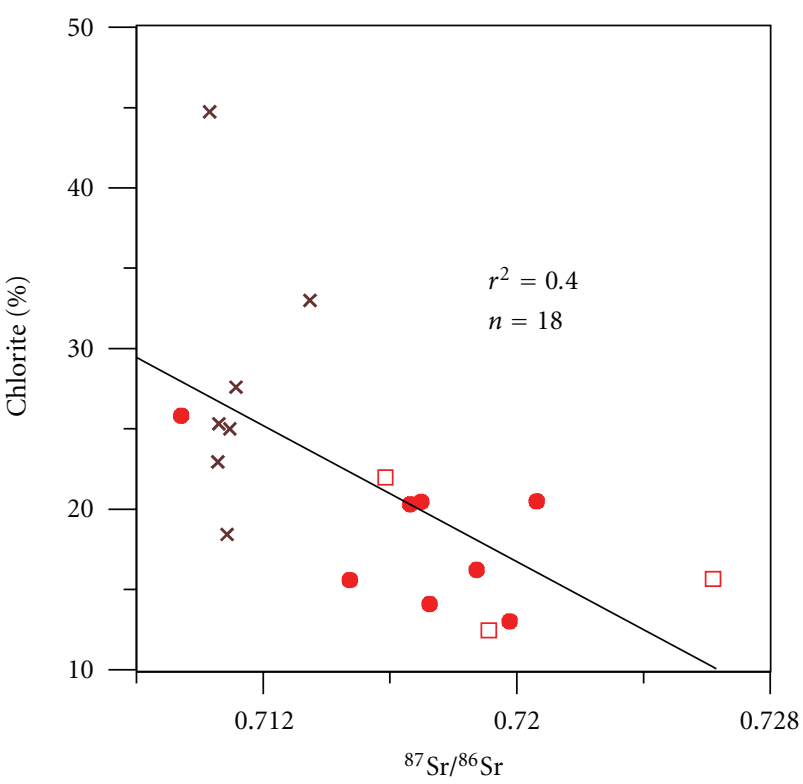

(b)

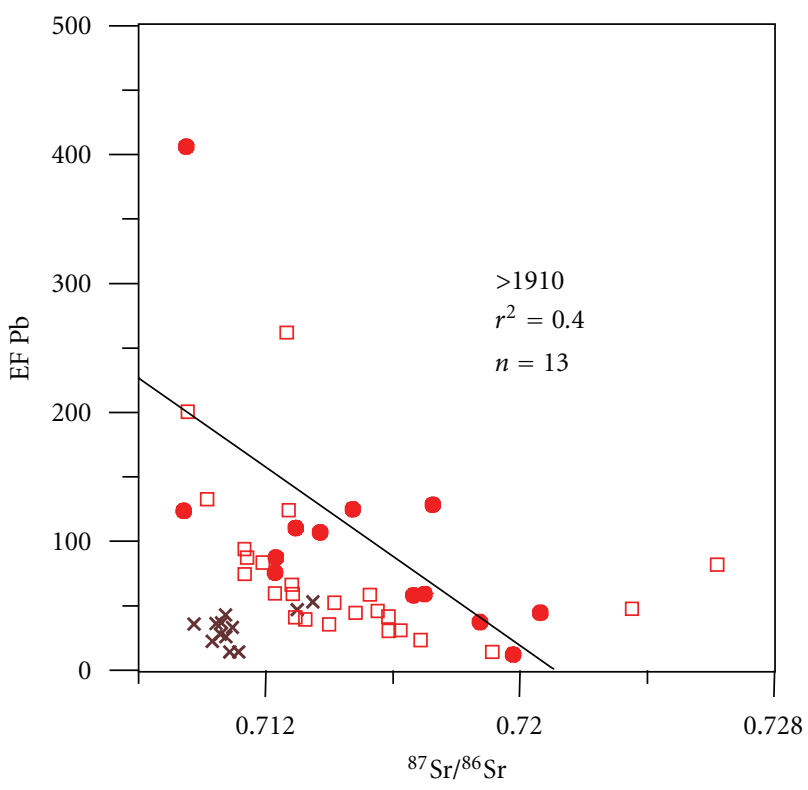

(d)

FIGURE 6: ${ }^{87} \mathrm{Sr} /{ }^{86} \mathrm{Sr}$ values as a function of the aerosol surface, the mica and chlorite contents, and the EF Pb for the Colle Gnifetti ice-core (CG, circles) and Jungfraujoch samples (JFJ, crosses). Pre-1910 CG samples are represented by empty squares, whereas post-1910 samples are represented by filled circles. Correlation coefficients are calculated over the entire dataset (CG record and JFJ samples), except for EF Pb (CG samples after 1910). The color-shaded areas correspond to the aerosol surface classes of Figure $3(<30 \mathrm{and}>100 \mathrm{~mm} / \mathrm{kg})$.

Industrial Revolution [4] (Figure 2). The isotopic composition of the soot carbon $\left(\delta^{13} \mathrm{C}_{\mathrm{BC}}\right)$ reflects dominant $\mathrm{C}_{3}$ $\left(\delta^{13} \mathrm{C}=-27 \%\right.$ ) woody pyrogenic emissions or fossil coal burning, while the decreasing trend observed in the $\delta^{13} \mathrm{C}_{\mathrm{BC}}$ values during the last century likely reflects increasing relative contribution from fossil fuel emissions $\left({ }^{13} \mathrm{C}\right.$ Suess effect; [4]) (Figure 2). Polycyclic Aromatic Hydrocarbons (PAHs) analysis from CG core also reveals exponentially increasing PAHs emissions from 1900, reaching maxima concentration levels in 1920 and 1940-1950 [52]. The present record, which ends with the 1977 Saharan dust event, therefore agrees with a significant decrease of anthropogenic lead emissions in the 1960s-1970s (Figure 2), thanks to more efficient emissions control. Nonetheless, the maxima BC concentrations occurred in the 1970s, whereas PAHs data furthermore show a renewed increase of anthropogenic pollutant emissions from 1975 to 2003 [52]. Additional data with a large spatial representation from shallow snow cores 
TABLE 3: The backward trajectory arrival date and source countries of the Sahara dust events collected at the Jungfraujoch (JFJ) Research Station, PM10 values and mean grain size.

\begin{tabular}{|c|c|c|c|c|c|}
\hline \multirow{2}{*}{$\begin{array}{l}\text { Sample name } \\
\text { I }\end{array}$} & \multicolumn{3}{|c|}{ Backward trajectory arrival date and origin (Figure 1) } & \multirow{2}{*}{$\begin{array}{c}\begin{array}{c}\text { PM10 } \\
\left(\mu \mathrm{g} / \mathrm{m}^{3}\right)\end{array} \\
26.2\end{array}$} & \multirow{2}{*}{$\begin{array}{c}\begin{array}{c}\text { Mean } \\
(\mu \mathrm{m})\end{array} \\
-\end{array}$} \\
\hline & 28.05 .2008 & $20 \mathrm{~h}$ & Libya, Tunisia & & \\
\hline $\mathrm{J}$ & 01.06 .2008 & $17 \mathrm{~h}$ & Morocco, Algeria, Tunisia & 12 & 4.0 \\
\hline A & 25.06.2008 & $23 \mathrm{~h}$ & Libya, Tunisia, Algeria & 45.1 & 3.9 \\
\hline $\mathrm{B}$ & 07.08.2008 & $3 \mathrm{~h}$ & Morocco & 9.8 & 4.0 \\
\hline $\mathrm{C}$ & 09.09 .2008 & $18 \mathrm{~h}$ & Algeria & 27.9 & 3.9 \\
\hline $\mathrm{D}$ & 10.09.2008 & $18 \mathrm{~h}$ & Libya, Tunisia, Algeria & 58.7 & 3.4 \\
\hline $\mathrm{K}$ & 11.09.2008 & $15 \mathrm{~h}$ & Algeria & 46.9 & - \\
\hline $\mathrm{L}$ & 13.10.2008 & $21 \mathrm{~h}$ & Algeria, Mali & 38.7 & - \\
\hline G & 13.05.2009 & $20 \mathrm{~h}$ & Libya, Algeria & 19 & 3.8 \\
\hline $\mathrm{H}$ & 24.05.2009 & $23 \mathrm{~h}$ & Morocco, Algeria & 22.2 & 4.3 \\
\hline $\mathrm{E}$ & 12.10.2009 & $23 \mathrm{~h}$ & West via Greenland & 1.1 & - \\
\hline $\mathrm{F}$ & 14.10 .2009 & $12 \mathrm{~h}$ & West via Greenland & 1.3 & - \\
\hline
\end{tabular}

would therefore be necessary to assess seasonal changes of natural and anthropogenic trace elements deposition, with respect to sources and atmospheric pathways (air-mass backtrajectories).

\section{Conclusions}

The mineral composition of the dust recovered in the high-altitude glaciers of Western Alps shows a relatively similar mineralogical composition (e.g., quartz and micas) as the local glaciogenic fine-grained sediments. However, the presence of kaolinite and palygorskite in the JFJ and CG samples clearly identify Saharan source, whereas these minerals were not observed in the silt and clay samples collected in the Grenz Glacier tills which show high amount of serpentines and amphibole. Saharan has been already identified as being the main source of the dust input over the high-altitude glaciers of the Western Alps during the last decades, and the isotopic signature of the insoluble aerosols transported to the Jungfraujoch research station and the Colle Gnifetti glacier further reveal (i) a Saharanderived source for the higher fluxes of dust transported by southwesterly winds during last centuries and (ii) low radiogenic Sr values for the daily PM10 aerosols and for the ice deposited during periods of low dust deposition. These results suggest a physical and chemical weathering effect on isotopic and elemental fractionations that requires further investigation on granulometric and mineralogical aerosol fractions.

The comparison of the $\mathrm{Sr}$ and $\mathrm{Nd}$ isotopic signatures from CG with those from Greenland cannot exclude that the Saharan dust sources possibly contribute, together with the Asian sources, to the long-range aeolian mineral aerosols deposited over Greenland during the last glacial period. However, further work based on the dust mineralogy and geochemistry of the geological sources and weathering/transport history are needed to address this hypothesis. Crustal element enrichment, mineral composition, and $\mathrm{Sr} / \mathrm{Nd}$ isotopic analyses demonstrate that North Africa was the most important supplier of mineral dust to the Western Alps throughout the last millennium. Highly resolved geochemical records of water soluble material from CG ice archive can therefore provide new perspectives on our understanding of interannual atmospheric circulation changes at this latitude and large-scale atmospheric interconnection patterns (e.g., NAO, MOC).

\section{Acknowledgments}

The Colle Gnifetti ice-core samples were provided while F. Thevenon was at the Geological Institute of ETH Zürich, with the support of Margit Schwikowski from the Paul Scherrer Institute and University of Bern (Switzerland). The drilling team, Paolo Gabrielli, Frederic Planchon, Beat Rufibach, Aurel Schwerzmann, Margit Schwikowski, and Dieter Stampfli is acknowledged for recovery of the Colle Gnifetti ice core. The coring was partly funded by the NCCR Climate project of the Swiss National Science Foundation (projects VITA and VIVALDI), the EU FP6 project MILLENNIUM (017008), the Istituto Nazionale per la Ricerca Scientifica e Tecnologica sulla Montagna (INRM) and the Agence de l'Environnement et de la Maîtrise de l'Energie (ADEME). The present research work was financially supported by a grant from the Swiss National Science Foundation (SNSF Ambizione fellowship PZ00P2_121994). The authors thank Martine Collaud Coen (MeteoSwiss, Payerne) for fruitful scientific exchanges on air-mass back-trajectories, Michèle Senn and Denis Fontignie (Department of Mineralogy, Geneva) for technical support in the sample preparation, and T. M. Jenk and M. Sigl for giving access to the age model of CG core. They thank anonymous reviewers for their constructive comments that led to a substantial improvement in the paper.

\section{References}

[1] M. de Angelis and A. Gaudichet, "Saharan dust deposition over Mont Blanc (French Alps) during the last 30 years," Tellus $B$, vol. 43, no. 1, pp. 61-75, 1991. 
[2] L. G. Thompson, T. Yao, E. Mosley-Thompson, M. E. Davis, K. A. Henderson, and P. N. Lin, "A high-resolution millennial record of the South Asian monsoon from Himalayan ice cores," Science, vol. 289, no. 5486, pp. 1916-1919, 2000.

[3] J. R. McConnell, A. J. Aristarain, J. R. Banta, P. R. Edwards, and J. C. Simoes, "20th-Century doubling in dust archived in an Antarctic Peninsula ice core parallels climate change and desertification in South America," Proceedings of the National Academy of Sciences of the United States of America, vol. 104, no. 14, pp. 5743-5748, 2007.

[4] F. Thevenon, F. S. Anselmetti, S. M. Bernasconi, and M. Schwikowski, "Mineral dust and elemental black carbon records from an Alpine ice core (Colle Gnifetti glacier) over the last millennium," Journal of Geophysical Research, vol. 114, no. 17, Article ID D17102, 11 pages, 2009.

[5] IPCC, "Changes in atmospheric constituents and in radiative forcing," in Climate Change 2007: The Physical Basis, P. Forster, V. Ramaswamy, P. Artaxo et al., Eds., pp. 129-234, Cambridge University Press, New York, NY, USA, 2007.

[6] F. E. Grousset and P. E. Biscaye, "Tracing dust sources and transport patterns using $\mathrm{Sr}, \mathrm{Nd}$ and $\mathrm{Pb}$ isotopes," Chemical Geology, vol. 222, no. 3-4, pp. 149-167, 2005.

[7] B. Delmonte, P. S. Andersson, H. Schoberg et al., "Geographic provenance of aeolian dust in East Antarctica during Pleistocene glaciations: preliminary results from Talos Dome and comparison with East Antarctic and new Andean ice core data," Quaternary Science Reviews, vol. 29, no. 1-2, pp. 256264, 2010.

[8] A. Svensson, P. E. Biscaye, and F. E. Grousset, "Characterization of late glacial continental dust in the Greenland Ice Core Project ice core," Journal of Geophysical Research, vol. 105, no. 4, pp. 4637-4656, 2000.

[9] A. J. M. Bory, P. E. Biscaye, A. Svensson, and F. E. Grousset, "Seasonal variability in the origin of recent atmospheric mineral dust at NorthGRIP, Greenland," Earth and Planetary Science Letters, vol. 196, no. 3-4, pp. 123-134, 2002.

[10] B. Delmonte, J. R. Petit, K. Andersen, I. Basile-Doelsch, V. Maggi, and V. Lipenkov, "Dust size evidence for opposite regional atmospheric circulation changes over east Antarctica during the last climatic transition," Climate Dynamics, vol. 23, no. 3-4, pp. 427-438, 2004.

[11] J. Xu, S. Hou, D. Qin et al., "A 108.83-m ice-core record of atmospheric dust deposition at Mt. Qomolangma (Everest), Central Himalaya," Quaternary Research, vol. 73, no. 1, pp. 3338, 2010.

[12] P. Vallelonga, P. Gabrielli, I. Balliana et al., "Lead isotopic compositions in the EPICA Dome C ice core and Southern Hemisphere potential source areas," Quaternary Science Reviews, vol. 29, no. 1-2, pp. 247-255, 2010.

[13] M. Collaud Coen, E. Weingartner, D. Schaub et al., "Saharan dust events at the Jungfraujoch: detection by wavelength dependence of the single scattering albedo and first climatology analysis," Atmospheric Chemistry and Physics, vol. 4, no. 11-12, pp. 2465-2480, 2004.

[14] T. Moreno, X. Querol, S. Castillo et al., "Geochemical variations in aeolian mineral particles from the Sahara-Sahel dust corridor," Chemosphere, vol. 65, no. 2, pp. 261-270, 2006.

[15] T. M. Jenk, S. Szidat, D. Bolius et al., "A novel radiocarbon dating technique applied to an ice core from the Alps indicating late Pleistocene ages," Journal of Geophysical Research, vol. 114, Article ID D14305, 8 pages, 2009.

[16] S. Nyeki, F. Li, D. Rosser, I. Colbeck, and U. Baltensperger, "The background aerosol size distribution at a high-alpine site: an analysis of the seasonal cycle," Journal of Aerosol Science, vol. 28, no. 1, pp. 211-212, 1997.
[17] A. K. Overton, "Jungfraujoch high altitude research station," Weather, vol. 63, no. 3, pp. 76-79, 2008.

[18] T. Tanaka, S. Togashi, H. Kamioka et al., "JNdi-1: a neodymium isotopic reference in consistency with LaJolla neodymium," Chemical Geology, vol. 168, no. 3-4, pp. 279-281, 2000.

[19] S. B. Jacobsen and G. J. Wasserburg, "Sm-Nd isotopic evolution of chondrites," Earth and Planetary Science Letters, vol. 50, no. 1, pp. 139-155, 1980.

[20] T. Adatte, W. Stinnesbeck, and G. Keller, "Lithostratigraphic and mineralogic correlations of near K/T boundary sediments northeastern Mexico: implications for origin and nature of deposition," in The Cretaceous-Tertiary Event and Other Catastrophes in Earth History, vol. 307, pp. 211-226, Geological Society of America, Boulder, Colo, USA, 1996.

[21] P. Y. Favarger, B. A. Thomas, C. Guéguen, and F. Monna, "Evaluation of simultaneous ICP-MS/OES sediment analysis based on reference samples," in Proceedings of the 6th Symposium on Analytical Sciences, Valencia, Spain, June 1998.

[22] C. Guéguen, J. Dominik, M. Pardos, C. Benninghoff, and R. L. Thomas, "Partition of metals in the Vistula River and in effluents from sewage treatment plants in the region of Cracow," Lakes and Reservoirs, vol. 5, no. 2, pp. 59-66, 2000.

[23] K. H. Wedepohl, "The composition of the continental crust," Geochimica et Cosmochimica Acta, vol. 59, no. 7, pp. 12171232, 1995.

[24] P. E. Biscaye, F. E. Grousset, M. Revel et al., "Asian provenance of glacial dust (stage 2) in the Greenland Ice Sheet Project 2 ice core, Summit, Greenland," Journal of Geophysical Research, vol. 102, no. 12, pp. 26765-26781, 1997.

[25] F. E. Grousset, M. Parra, A. Bory et al., "Saharan wind regimes traced by the $\mathrm{Sr}-\mathrm{Nd}$ isotopic composition of subtropical Atlantic sediments: last glacial maximum vs today," Quaternary Science Reviews, vol. 17, no. 4-5, pp. 395-409, 1998.

[26] C. Pin, D. Briot, C. Bassin, and F. Poitrasson, "Concomitant separation of strontium and samarium-neodymium for isotopic analysis in silicate samples, based on specific extraction chromatography," Analytica Chimica Acta, vol. 298, no. 2, pp. 209-217, 1994.

[27] R. D. Evans, I. F. Jefferson, R. Kumar, K. O’Hara-Dhand, and I. J. Smalley, "The nature and early history of airborne dust from North Africa; in particular the Lake Chad basin," Journal of African Earth Sciences, vol. 39, no. 1-2, pp. 81-87, 2004.

[28] D. Wagenbach and K. Geis, "The mineral dust record in a high altitude alpine glacier (Colle Gnifetti, Swiss Alps)," in Paleoclimatology and Paleometeorology: Modern and Past Patterns of Global Atmospheric Transport, M. Leinen and M. Sarnthein, Eds., (NATO ASI Series C, Vol. 282), pp. 543-564, Kluwer Academic Publishers, Boston, Mass, USA, 1989.

[29] H. Sodemann, A. Palmer, C. Schwierz, M. Schwikowski, and H. Wernli, "The transport history of two Saharan dust events archived in an Alpine ice core," Atmospheric Chemistry and Physics, vol. 6, no. 3, pp. 667-688, 2006.

[30] H. M. Roberts, D. R. Muhs, A. G. Wintle, G. A. T. Duller, and E. A. Bettis, "Unprecedented last-glacial mass accumulation rates determined by luminescence dating of loess from western Nebraska," Quaternary Research, vol. 59, no. 3, pp. 411-419, 2003.

[31] N. M. Mahowald, D. R. Muhs, S. Levis et al., "Change in atmospheric mineral aerosols in response to climate: last glacial period, preindustrial, modern, and doubled carbon dioxide climates," Journal of Geophysical Research, vol. 111, Article ID D10202, 2006. 
[32] G. R. Burton, K. J. R. Rosman, K. P. van de Velde, and C. F. Boutron, "A two century record of strontium isotopes from an ice core drilled at Mt Blanc, France," Earth and Planetary Science Letters, vol. 248, no. 1-2, pp. 202-211, 2006.

[33] R. Glaccum and J. M. Prospero, "Saharan aerosols over the tropical North Atlantic-Mineralogy," Marine Geology, vol. 37, no. 3-4, pp. 295-321, 1980.

[34] A. Avila, I. Queralt-Mitjans, and M. Alarcón, "Mineralogical composition of African dust delivered by red rains over northeastern Spain," Journal of Geophysical Research, vol. 102, no. 18, pp. 21977-21996, 1997.

[35] S. Caquineau, A. Gaudichet, L. Gomes, and M. Legrand, "Mineralogy of Saharan dust transported over northwestern tropical Atlantic ocean in relation to source regions," Journal of Geophysical Research, vol. 107, no. 15, 12 pages, 2002.

[36] L. A. Fiol, J. J. Fornos, B. Gelabert, and J. A. Guijarro, "Dust rains in Mallorca (Western Mediterranean): their occurrence and role in some recent geological processes," Catena, vol. 63, no. 1, pp. 64-84, 2005.

[37] F. Thevenon, M. Chiaradia, T. Adatte, C. Hueglin, and J. Poté, "Ancient versus modern mineral dust transported to highaltitude Alpine glaciers evidences Saharan sources and atmospheric circulation changes," Atmospheric Chemistry and Physics Discussions, vol. 11, pp. 859-884, 2011.

[38] T. Pettke and L. W. Diamond, "Rb-Sr dating of sphalerite based on fluid inclusion-host mineral isochrons: a clarification of why it works," Economic Geology, vol. 91, no. 5, pp. 951-956, 1996.

[39] H. C. Moor, T. Schaller, and M. Sturm, "Recent changes in stable lead isotope ratios in sediments of Lake Zug, Switzerland," Environmental Science and Technology, vol. 30, no. 10, pp. 2928-2933, 1996.

[40] D. Weiss, W. Shotyk, and O. Kempf, "Archives of atmospheric lead pollution,” Naturwissenschaften, vol. 86, no. 6, pp. 262 275, 1999.

[41] J. Nriagu, "Global metal pollution: poisoning the biosphere?" Environment, vol. 32, no. 7, pp. 28-32, 1990.

[42] M. L. Geagea, P. Stille, F. Gauthier-Lafaye, and M. Millet, "Tracing of industrial aerosol sources in an urban environment using $\mathrm{Pb}, \mathrm{Sr}$, and $\mathrm{Nd}$ isotopes," Environmental Science and Technology, vol. 42, no. 3, pp. 692-698, 2008.

[43] H. W. Nesbitt, G. Markovics, and R. G. Price, "Chemical processes affecting alkalis and alkaline earths during continental weathering," Geochimica et Cosmochimica Acta, vol. 44, no. 11, pp. 1659-1666, 1980.

[44] J. D. Blum and Y. Erel, "Rb-Sr isotope systematics of a granitic soil chronosequence: the importance of biotite weathering," Geochimica et Cosmochimica Acta, vol. 61, no. 15, pp. 3193 3204, 1997.

[45] R. R. Draxler and G. D. Rolph, HYSPLIT_-Hybrid Single Particle Lagrangian Integrated Trajectory Model Access via NOAA ARL READY Website, NOAA Air Resources Laboratory, Silver Spring, Md, USA, 2003.

[46] F. Grousset, P. Ginoux, A. Bory, and P. Biscaye, "Case study of a Chinese dust plume reaching the French Alps," Geophysical Research Letters, vol. 30, no. 6, p. 1277, 2003.

[47] C. Kang et al., "Dust records from three ice cores: relationships to spring atmospheric circulation over the Northern Hemisphere," Atmospheric Environment, vol. 37, no. 34, pp. 48234835, 2003.

[48] I. Chiapello and C. Moulin, "TOMS and METEOSAT satellite records of the variability of Saharan dust transport over the Atlantic during the last two decades (1979-1997)," Geophysical Research Letters, vol. 29, no. 1176, pp. 17-20, 2002.
[49] M. F. Glueck and C. W. Stockton, "Reconstruction of the North Atlantic oscillation, 1429-1983," International Journal of Climatology, vol. 21, no. 12, pp. 1453-1465, 2001.

[50] D. T. Shindell, G. A. Schmidt, M. E. Mann, D. Rind, and A. Waple, "Solar forcing of regional climate change during the Maunder Minimum," Science, vol. 294, no. 5549, pp. 21492152, 2001.

[51] D. C. Lund, J. Lynch-Stieglitz, and W. B. Curry, "Gulf Stream density structure and transport during the past millennium," Nature, vol. 444, no. 7119, pp. 601-604, 2006.

[52] J. Gabrieli, P. Vallelonga, G. Cozzi et al., "Post 17th-century changes of European PAH emissions recorded in high-altitude alpine snow and ice," Environmental Science and Technology, vol. 44, no. 9, pp. 3260-3266, 2010. 

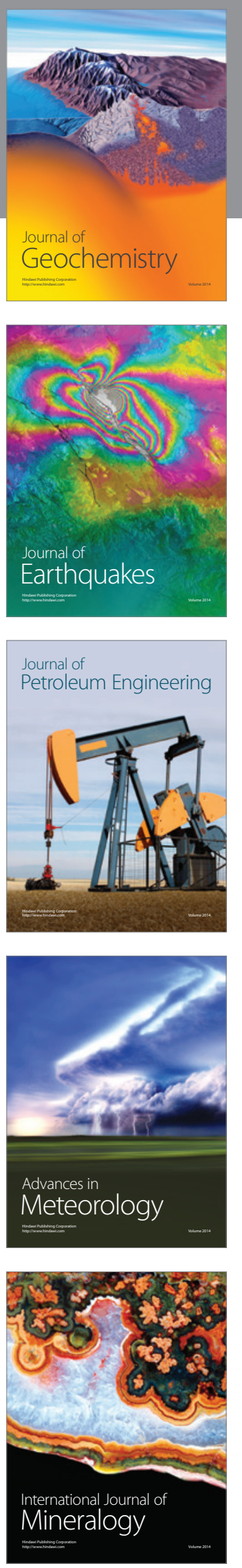
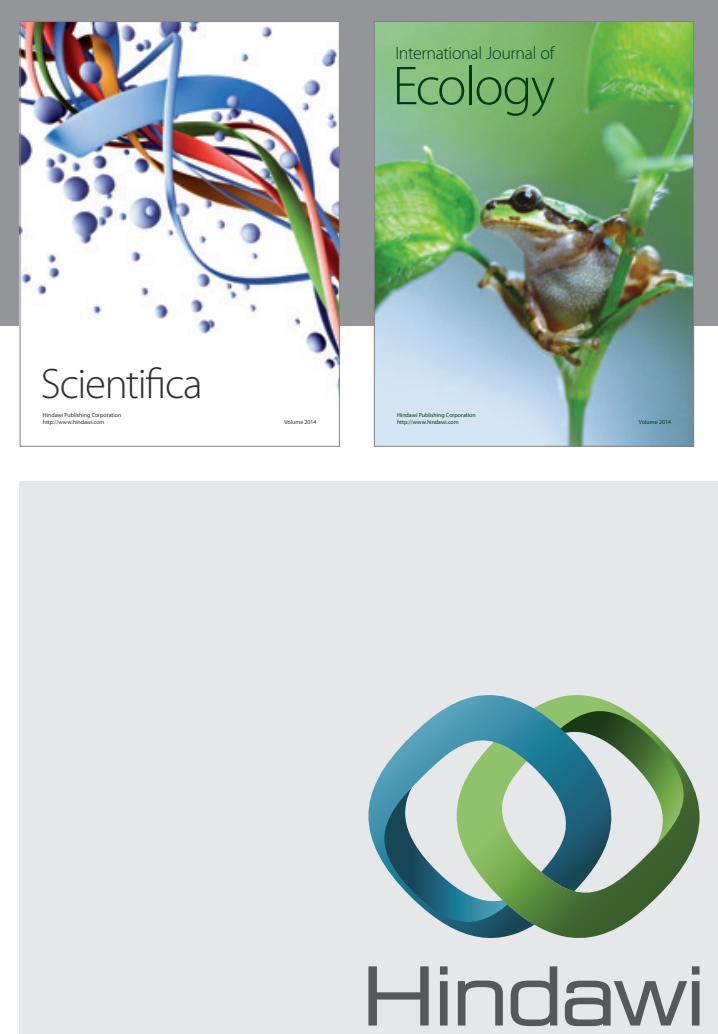

Submit your manuscripts at http://www.hindawi.com
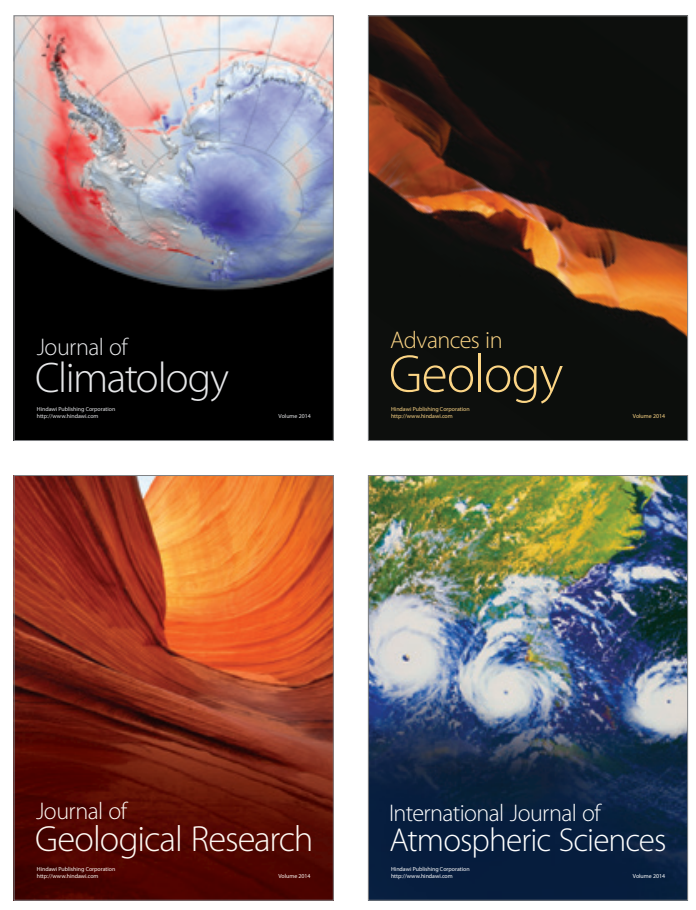
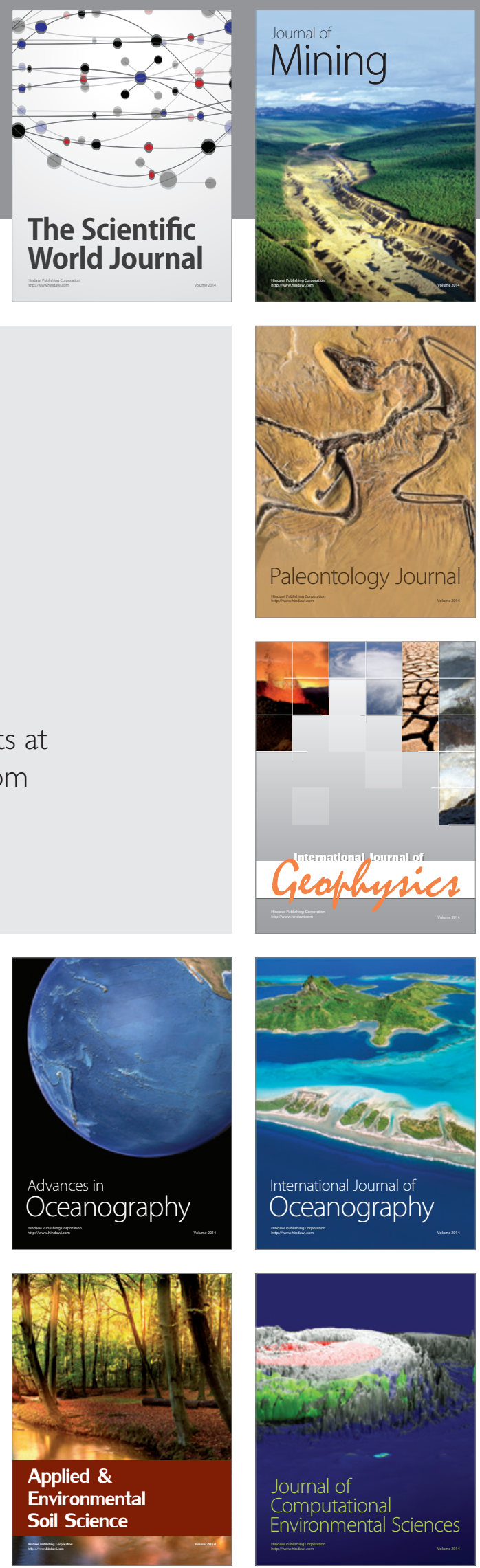